Gut, 1960, 1, 163.

\title{
A REPORT OF TWO CASES OF WHIPPLE'S DISEASE DIAGNOSED BY PERORAL SMALL INTESTINAL BIOPSY
}

\author{
BY \\ C. J. DICKINSON, M. HARTOG, and MARGOT SHINER \\ From the Professorial Medical Unit, Middlesex Hospital, London, St. Mary's Hospital, London, and \\ the Department of Gastroenterology, Central Middlesex Hospital, London
}

Two patients with Whipple's disease are described in whom the diagnosis was established by peroral small intestinal biopsy. Scurvy occurred in one patient.

Whipple's disease was first described in 1907. It is a rare disease, affecting predominantly men in middle life. Its clinical manifestations are those of a malabsorption syndrome. Certain other features, such as generalized lymphadenopathy and polyserositis or a history of preceding fleeting polyarthritis, lead to suspicion of Whipple's disease.

Fleeting arthritis may precede the diarrhoea and steatorrhoea by many years. Diagnosis rests essentially on histological grounds, the typical features being infiltration of macrophages into the wall of the small intestine and into mesenteric and sometimes peripheral lymph nodes. These macrophages contain a material which gives a purple-pink reaction with periodic-acid-Schiff stains, thus identifying it as mucopolysaccharide. In addition large cystic spaces are seen in these tissues, which may be dilated lymphatics, containing sudanophilic material.

The diagnosis of Whipple's disease usually presents difficulties. Until 1947 diagnosis was generally made at necropsy only. With wider recognition of the symptoms, diagnostic laparotomy became a recognized procedure. In 1955, Puite and Tesluk described for the first time three patients in whom the diagnosis of Whipple's disease was established by peripheral gland biopsy. But others (Upton, 1952) found the histology of similar glands unhelpful, and were forced to proceed to laparotomy.

We report two cases of Whipple's disease in order to call attention to the possibility of making the diagnosis by peroral small intestinal biopsy (Shiner, 1956) and also because of certain unusual features noted in one of our cases.

\section{CASE Reports}

CASE 1.-A man, aged 35, had had no significant previous illnesses except occasional attacks of diarrhoea in the tropics while in the Navy. His present illness began in 1946 with fleeting arthritis affecting the shoulders and knees. This subsided in a few months. In 1950 arthritis, affecting mainly the joints of the wrists and fingers, recurred. It was not until 1955 that he began to complain of colicky abdominal pain, sometimes accompanied by vomiting. In March, 1956, he developed a purpuric rash on the legs and also bleeding of the gums. The diagnosis of scurvy was then made at another hospital and the skin and gum manifestations cleared up within a few days of receiving two doses each of $4 \mathrm{~g}$. of ascorbic acid orally. He was maintained on two capsules of "vitaminorum", N.F., daily and remained fairly well for the next five months. Thereafter he deteriorated, complaining of weakness, cough, diarrhoea, and increasing pigmentation, and he was finally admitted under Dr. Litchfield to St. Mary's Hospital in August, 1957.

On examination he was a thin, ill-looking man. There was brown pigmentation of the face and palate. The axillary and inguinal glands were moderately enlarged. The abdomen was somewhat distended and doughy in consistency. The liver and spleen were not felt. The joints appeared normal. Blood pressure was $90 / 60 \mathrm{~mm}$. Hg. Biopsy of one inguinal gland showed a considerable amount of periodic-acid-Schiff-positive staining material but a similar lymph node taken from a control subject contained the same material, though to a lesser extent. Results of the investigations are summarized in Table $I$.

Further Progress. - On admission the vitamin supplements were discontinued and he was given an ordinary ward diet. Ten days later a perifollicular purpuric rash appeared on the legs, accompanied by bleeding from the gums. A diagnosis of scurvy was made. The clinical manifestations of scurvy subsided within a few days of treatment with $700 \mathrm{mg}$. ascorbic acid a day by mouth. Table II shows the results of the ascorbic acid saturation test. The excretion of over $50 \mathrm{mg}$. ascorbic acid/10 stone body weight has been considered by Harris (1943), using a slightly different form of the test, to mark the approach 
TABLE I

RESULTS OF INVESTIGATIONS

\begin{tabular}{|c|c|c|}
\hline Inves & Case 1 & Case 2 \\
\hline $\begin{array}{l}\text { White cell count } \\
\text { Prothrombin time (one-stage) } \\
\text { E.S.R. (Westergren, one hour) } \\
\text { Serum electrolytes: } \\
\text { Sodium } \\
\text { Chloride } \\
\text { Potassium } \\
\text { Bicarbonate } \\
\text { Serum proteins } \\
\text { Total } \\
\text { Albumin } \\
\text { Globulin } \\
\text { Serum calcium } \\
\text { Serum inorganic phosphate } \\
\text { Serum alkaline phosphatase } \\
\text { Serum cholesterol } \\
\text { Serum B B concentration } \\
\text { Folic acid absorption test } \\
\text { Rose-Waaler test } \\
\text { Total faecal fats (3-day collection, patient on } \\
\text { normal diet) } \\
\text { Occult blood in stools } \\
\text { Glucose tolerance test (standard, oral) (half- } \\
\text { hourly) } \\
\text { Pancreatic enzymes } \\
\text { Barium meal and follow-through } \\
\text { Peripheral lymph node biopsy }\end{array}$ & 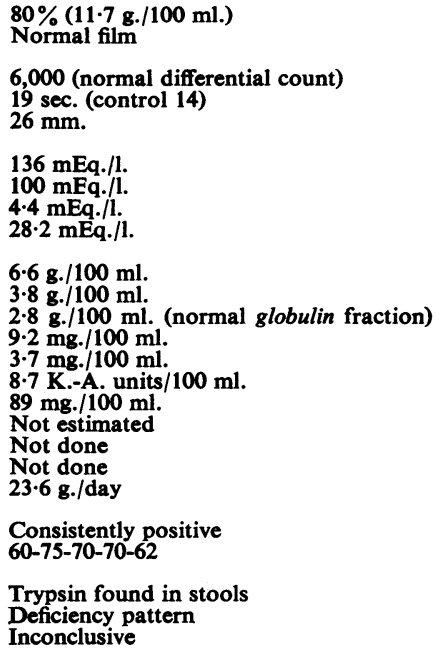 & 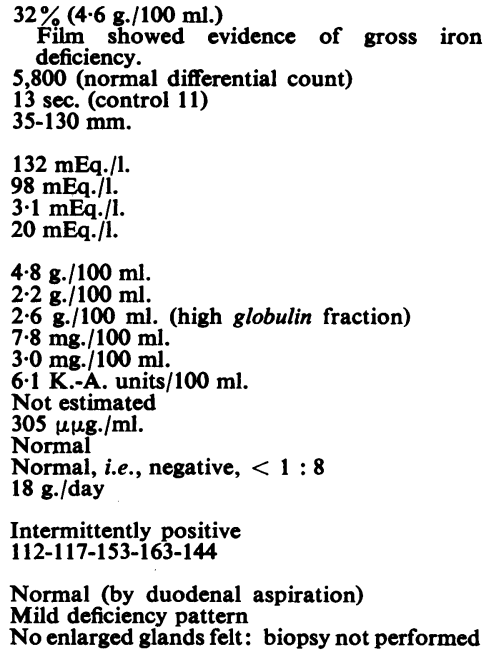 \\
\hline
\end{tabular}

of saturation. In our patient this did not occur until he was given $2 \mathrm{~g}$. ascorbic acid daily by mouth.

TABLE II

\begin{tabular}{l|c|c}
\hline Date & $\begin{array}{c}\text { Urinary Ascorbic Acid } \\
\text { Level (mg.) } \\
(10 \text { a.m.-3 p.m.) }\end{array}$ & $\begin{array}{c}\text { Dose of Ascorbic Acid } \\
\text { Given at 8 a.m. }\end{array}$ \\
\hline $\begin{array}{l}\text { Oct. 15, 1957 } \\
\text { Oct. 28, 1957 }\end{array}$ & $\begin{array}{c}22.0 \\
5.5\end{array}$ & $\begin{array}{c}0.7 \text { g./day (oral) con- } \\
\text { tinued in same dose } \\
\text { until: }\end{array}$ \\
\hline Oct. 29, 1957 & 18.5 & $\begin{array}{c}\text { Single dose of } 0.7 \mathrm{~g} . \\
\text { intravenously }\end{array}$ \\
\hline $\begin{array}{l}\text { Nov. 1, 1957 } \\
\text { Nov. 4, 1957 }\end{array}$ & 52.0 & $\begin{array}{c}2.0 \text { g./day (oral) con- } \\
\text { tinued in same dose }\end{array}$ \\
\hline
\end{tabular}

On additional treatment with a low-fat diet and mist. bismuth et opii, the diarrhoea diminished and he was able to return to work for the next six months. His improvement was not maintained and a further exacerbation of diarrhoea, accompanied by weight loss and weakness, necessitated his second admission to hospital in July, 1958. Treatment with A.C.T.H., 120 units, daily, was then begun and later changed to oral prednisone, $80 \mathrm{mg}$. daily, and finally to intravenous hydrocortisone. Despite this, his condition continued to deteriorate and he died two months after admission. Post-mortem examination revealed gross atrophy of the small intestinal mucosa together with widespread enlargement of the lymph glands, particularly marked in the mesenteric glands. In addition there were vegetations on two of the cusps of the aortic valve.

CASE 2.-A man aged 47, mentally defective owing to severe birth trauma, had had no serious illnesses until 1954, when he began to lose weight and complained of vague general ill health. In 1955, there was transient swelling of the legs and hands with pitting oedema, and he complained of pain in the legs, back, neck, and shoulders. Between 1955 and 1957 he had frequent attacks of winter cough. Early in 1957 he began to have diarrhoea, passing two to four pale, bulky, offensive-smelling stools daily. Thereafter his rapid weight loss and increasing breathlessness led to investigation at his local hospital where a diagnosis of idiopathic steatorrhoea was made. Despite a low-fat diet and supplements of iron and folic acid by mouth he deteriorated still further and was admitted to the Middlesex Hospital under Professor Kekwick in September, 1957.

On examination he was desperately ill. He was pale and dyspnoeic, with gross oedema of the legs, thighs, and abdominal wall, tense ascites, bilateral purulent conjunctivitis, clubbing of the finger and toe nails, and a raised jugular venous pressure. The muscles were very wasted and his skin was dry, inelastic, and slightly pigmented. The peripheral lymph glands were not palpable. Widespread rales and rhonci were heard in all areas of the chest. Investigations are summarized in Table I.

Energetic treatment with penicillin, digitalis, transfusion of packed cells, parenteral iron, and vitamins resulted in rapid improvement after 10 days.

Further Progress.-His illness followed a fluctuating course with episodes of fever, diarrhoea, and a painful effusion into the right knee joint two months after admission. He improved for a considerable time after this and remained well for nine months, although he still had diarrhoea and a hypochromic anaemia resistant to parenteral iron therapy. Because of general deterioration and increasing anaemia he was readmitted to hospital in November, 1958.

Symptomatic treatment of diarrhoea did not help, and he was started on prednisone, $10 \mathrm{mg}$. t.d.s. He 
improved a little and the diarrhoea diminished. Ten days after starting prednisone he suddenly collapsed with signs of acute peripheral circulatory failure and died.

Post-mortem examination showed maldevelopment of the left cerebral hemisphere and vegetations on a bicuspid aortic valve. The whole length of small intestine was grossly distended with thin black fluid and its wall showed extreme congestion and oedema. There was no obstruction of the mesenteric arteries and histological examination did not suggest infarction. Culture of the small bowel contents yielded only $B$. proteus and coliform bacilli. Histological examination of the small intestinal wall and mesenteric lymph glands confirmed the diagnosis of Whipple's disease. The cause of death seems obscure but could possibly have resulted from rapid transit of fluid from the circulation to the gut lumen.

\section{Histology}

CASE 1.-Three mucosal specimens were obtained by peroral intestinal intubation from the upper part of the jejunum. These included full-thickness mucosa (Fig. 1a).
The villi appeared markedly distended, shortened, and clubbed, due to numerous macrophages in the villous stroma (Fig. 1b). Similarly, the interglandular stroma of the lamina propria was seen to contain macrophages but to a much lesser degree. With the periodic-acidSchiff stain these macrophages stained a purple pink.

Goblet cells were seen in excess in between villous and glandular cells and there was also some increase in inflammatory cells, mainly in the form of polymorphonuclears, both in the mucosa and submucosa.

CASE 2.-Six full-thickness mucosal specimens were obtained from the first part of the jejunum. All showed periodic-acid-Schiff-positive staining macrophages, distributed mainly in the interglandular stroma of the lamina propria (Figs. 2a and b). In contrast to Case 1, the villi, though irregular in shape, were of normal height and width and the upper third of the villi was almost entirely free from macrophage infiltration, whereas the glandular layer was much increased in thickness. No increase in goblet or inflammatory cells was observed.

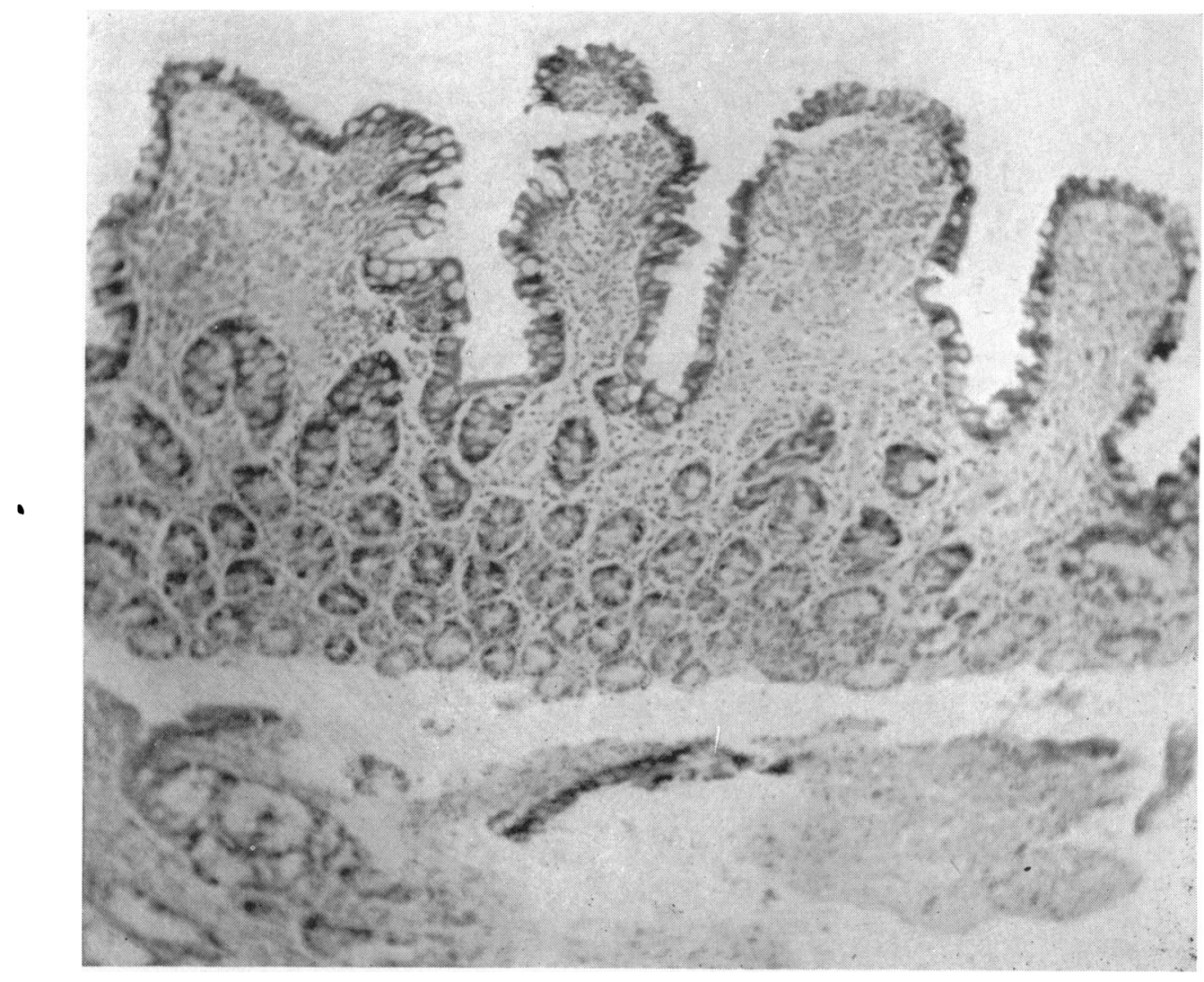

Fig. 1a.-Low-power view of jejunal mucosa from Case 1, showing shortening and distension of villi due to cellular infiltration and an increase in goblet cells. Haematoxylin and eosin $\times 100$. 


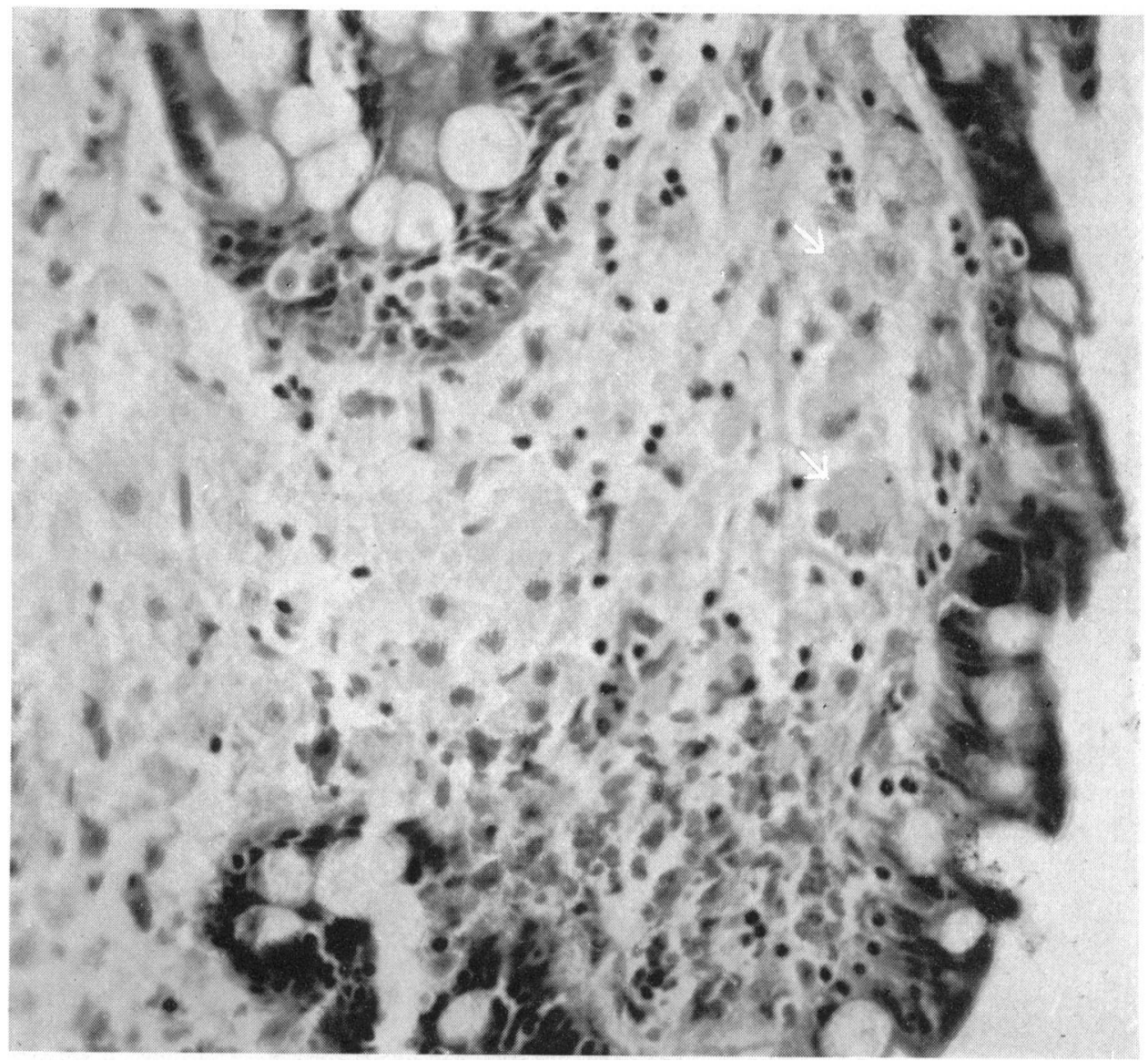

FIG. 1b.-High-power view of a distended villus from Fig. 1a, arrows pointing to typical macrophage cells. Haematoxylin and eosin $\times 400$.

Discussion

Whipple's disease is almost invariably fatal, the duration of the illness lasting from five to 10 years or longer from the onset of first symptoms. Scurvy is a well-recognized complication of the malabsorption syndrome but is uncommon. Still (1918) reported it in four cases of coeliac disease but it has not, to our knowledge, previously been described in Whipple's disease.

The slow response of the urinary ascorbic acid excretion as compared with the rapid clinical improvement as soon as treatment with ascorbic acid is begun, is known to occur in scurvy (Schultzer, 1936). In addition, Boscott and Cooke (1954) drew attention to the fact that saturation with ascorbic acid may be delayed in steatorrhoea and that this may occur even when the ascorbic acid is given parenterally. The daily requirements of ascorbic acid are somewhat controversial. Minimal daily requirements have been quoted as $15 \mathrm{mg}$. (Kellie and Zilva, 1939) to $75 \mathrm{mg}$. (Scheunert, 1949). After the first attack of scurvy, the normal diet of Case 1 was supplemented with $30 \mathrm{mg}$. ascorbic acid and two oranges daily (providing about $100 \mathrm{mg}$. ascorbic acid). Only 10 days after discontinuing these supplements he developed frank scurvy. A normal volunteer maintained on a vitamin-C-deficient diet did not develop scurvy until he had been on this diet for 161 days (Crandon, Lund, and Dill, 1940). In a similar experiment performed upon himself in the eighteenth century, William Stark developed scurvy only after two months (Drummond and Wilbraham, 1935). The rapidity with which our patient developed scurvy suggests that his previous intake of ascorbic acid represented what was for him the critical minimum requirement.

We have no information in Case 2 about his absorption of ascorbic acid, since large doses were 


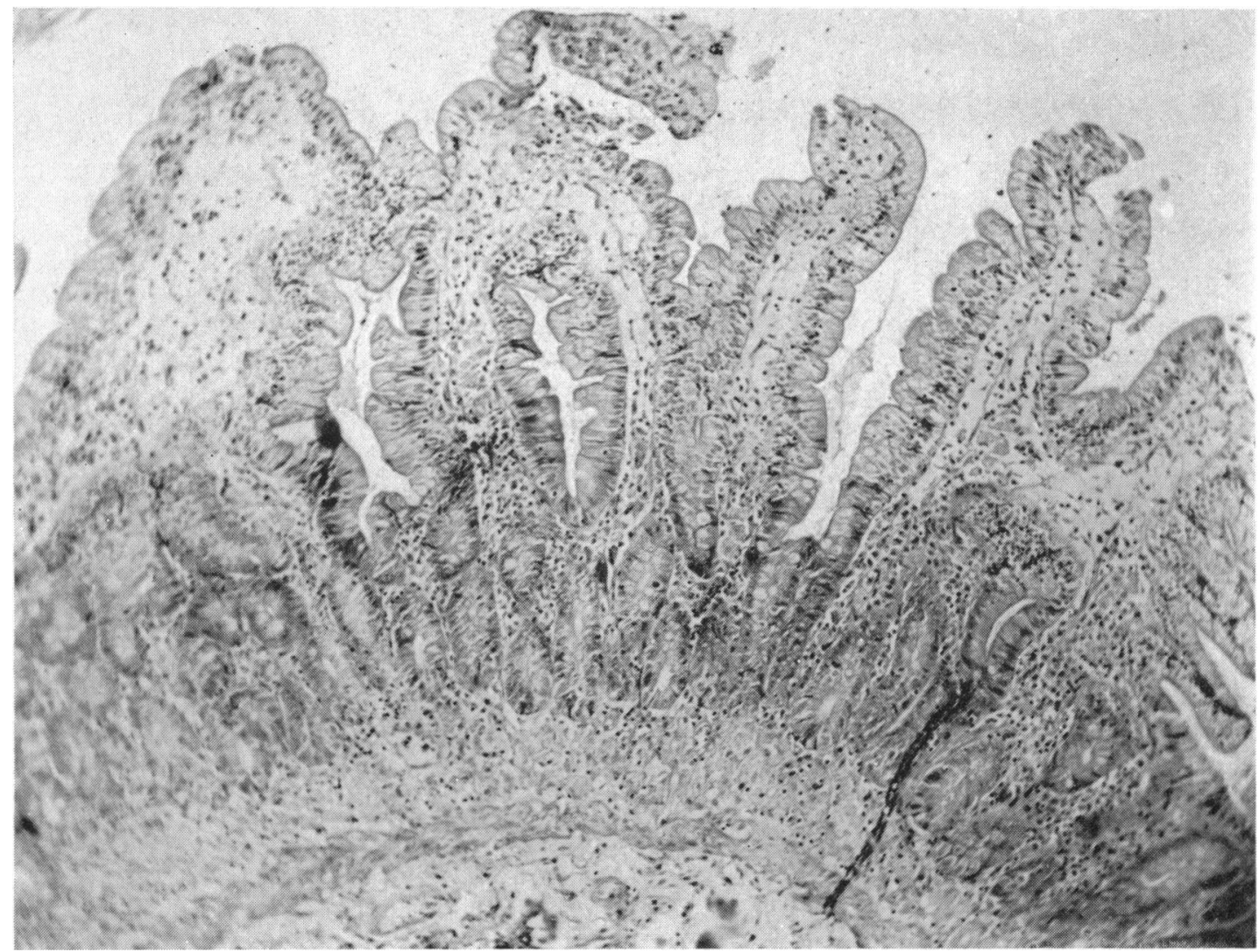

FiG. 2a.-Low-power view of jejunal mucosa from Case 2, showing long villi free from cellular infiltration in their upper parts. Cells are densely packed in the intervillous stroma of the lower part of the villi and whole thickness of mucosa. Haematoxylin and eosin $\times 100$.

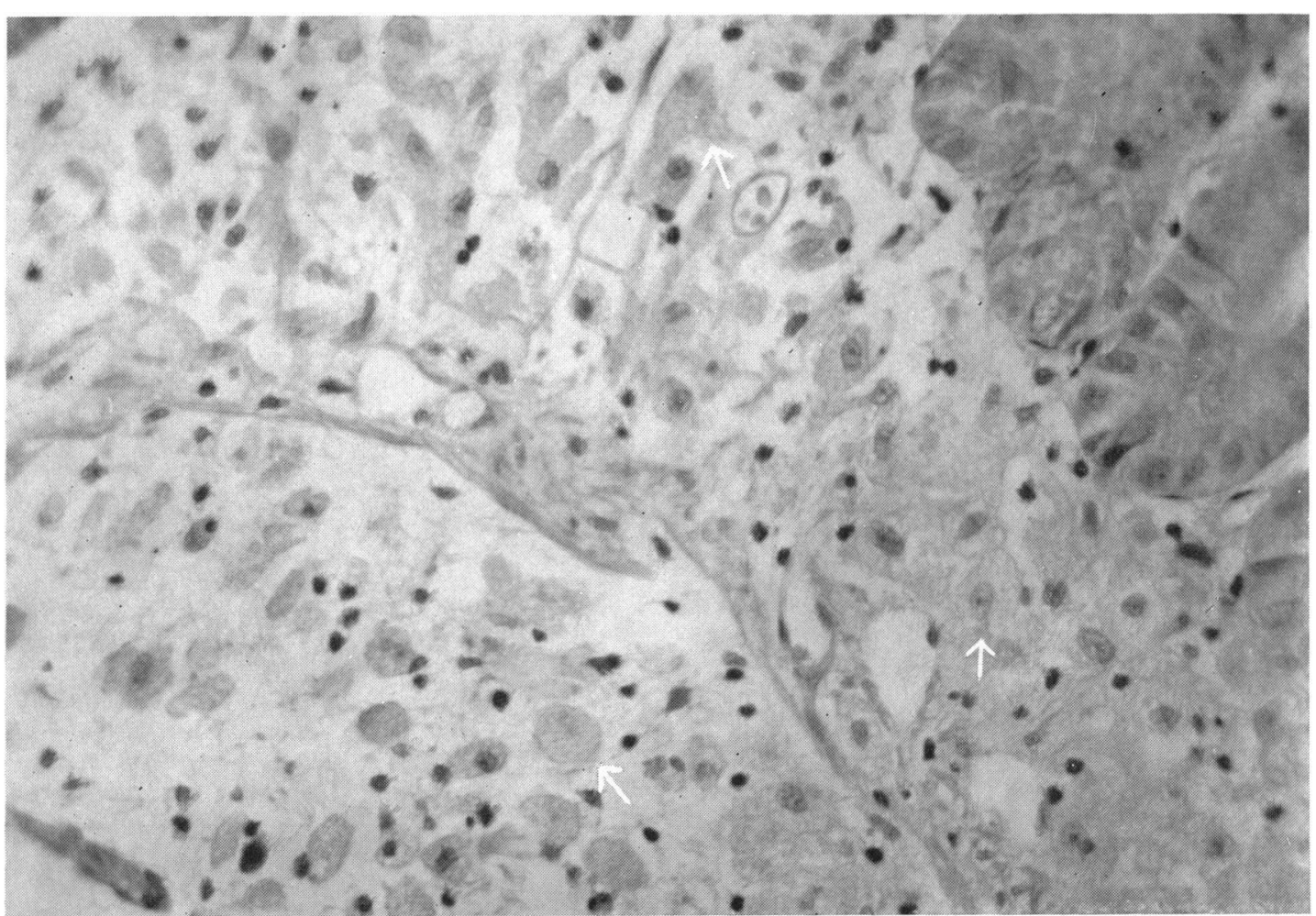

Fig. 2b.-High-power view of the lower part of the mucosa, muscularis mucosae, and submucosa from Fig. 2a, arrows pointing to macrophages above and below muscularis mucosae. Haematoxylin and eosin $\times 400$. 
given as part of his initial emergency treatment. Although our second case showed evidence of malabsorption of fat, of protein, and probably of vitamin $\mathrm{D}$, it is interesting to note that his absorption of folic acid was normal. This is in contrast to most cases of idiopathic steatorrhoea (Chanarin, Anderson, and Mollin, 1958). The serum $B_{12}$ concentration was also normal.

Diagnosis of Whipple's disease by peroral inintestinal biopsy causes little discomfort to the patient and avoids laparotomy. It should be carried out at an early stage in all cases suspected of Whipple's disease. The characteristic histological picture of Whipple's disease has been looked for in all of the $\mathbf{2 0 0}$ or more intestinal biopsies performed by the peroral method but has only been seen in the two cases described in this paper. These 200 biopsies included 75 cases of steatorrhoea from various causes.

Because of the poor prognosis in Whipple's disease, much discussion has evolved around the question of treatment with steroids or A.C.T.H. It has been stated by some authors (Wang, Janowitz, and Adlersberg, 1956; Schaffner and Scherbel, 1955) that the disease may be favourably influenced by steroids in its early stages. They reported on patients who showed improvement on corticoids over a follow-up period of 20 and 10 months respectively. However, the course of the disease is a long one with periods of exacerbations and remissions; and therefore any beneficial effect attributed to steroids must be interpreted with caution.
Repeated biopsies at various stages after treatment in Whipple's disease might give us objective evidence of improvement or otherwise. Finally, histochemical stains on the mucosal specimens may in the future enable the identification of the mucopolysaccharide material contained in the macrophages.

We are most grateful to Dr. J. W. Litchfield and to Professor A. Kekwick for kindly allowing us to study and report these cases under their care, and for their encouragement. We also wish to acknowledge the help and advice given to us by Dr. T. M. Chalmers, Dr. R. H. Heptinstall, Professor I. Doniach, Dr. R. A. B. Drury, Dr. J. F. Arthur, and Dr. R. Cotton. Dr. D. L. Mollin kindly performed the $\mathrm{B}_{12}$ estimations and Dr. I. Chanarin the folic acid absorption test; we are grateful for their permission to report the results. One of us (M.S.) gratefully acknowledges the assistance of the Medical Research Council from which a grant was received.

\section{REFERENCES}

Boscott, R. J., and Cooke, W. T. (1954). Quart. J. Med., 23, 307. Chanarin, I., Anderson, B. B., and Mollin, D. L. (1958). Brit. J. Haemat., 4, 156.

Crandon, J. H., Lund, C. C., and Dill, D. B. (1940). New Engl. J. Med., 223, 353.

Drummond, J. C., and Wilbraham, A. (1935). Lancet, 2, 459.

Harris, L. J. (1943). Ibid., 1, 515.

Karris, L. J. (1943). Ibid.y, 1, 515. Biochem. J., 33, 153.

Kellie, A. E., and Zilva, S. S. (1939). Biochem. J., 33, 153.

Pchaffiner, F., and Scherbel, A. L. (1955). Gastroenterology, 29, 109. Scheunert, Ż. (1949). Z. Vitamin-, Hormon-u. Fermentforsch, 20, 374.

Schultzer, P. (1936). Acta med. scand., 88, 317.

Shiner, M. (1956). Lancet, 1, 17.

Still, G. F. (1918). Ibid., 2, 163.

Upton, A. C. (1952). Amer. J. clin. Path., 22, 755.

Wang, C. I., Janowitz, H. D., and Adlersberg, D. (1956). Gastroenterology, 30, 475 . 